\title{
Conservation and Ecology of Lilium pyrophilum, a New Species of Liliaceae from the Sandhills Region of the Carolinas and Virginia, U.S.A.
}

\author{
Mark W. Skinner \\ USDA-NRCS, National Plant Data Center, P.O. Box 74490, Baton Rouge, Louisiana 70874, \\ U.S.A. mskinner@po.nres.usda.gov
}

\section{Bruce A. Sorrie}

3076 Niagara-Carthage Road, Whispering Pines, North Carolina 28327, U.S.A. bsorrie@earthlink.net

Abstract. Lilium pyrophilum M. W. Skinner \& Sorrie is a new taxon from the Sandhills region of the Atlantic Coastal Plain, where it is known from 16 counties in the Carolinas and adjacent Virginia. It occurs within the longleaf pine ecosystem in sandy, wet to dry ecotonal situations such as streamheads, seeps, swampy streams, and wet, maintained powerlines. Lilium pyrophilum is most closely allied to L. superbum but is allopatrically distributed and confined to a restricted habitat. Compared to L. superbum it blooms later, is smaller, has fewer and smaller flowers with slightly longer tubes, and it has shorter and relatively broader leaves that are ascending and concentrated in fewer whorls toward the bottom of the stem. Frequent fires are essential for habitat maintenance in natural settings, and thus the Latin epithet pyrophilum (= fire loving) is used for the new taxon. We suggest the common name Sandhills lily for this rare lily, and urge its fullest protection.

Key words: fire dependence, Liliaceae, Lilium, long-leaf pine ecosystem, North Carolina, South Carolina, U.S.A.,Virginia.

For some time botanists in the Sandhills region have known of the existence of an unusual and perhaps undescribed true lily. In their flora of the Carolinas, Radford et al. (1968) mentioned robust Lilium michauxii Poiret plants in bogs that resembled Lilium superbum L. It is these plants, previously masquerading in herbaria under both those names, that we describe here as L. pyrophilum.

Since its recognition as distinctive in the mid 1970s (Russo, 1997), the taxonomic identity of this new lily has been debated. As Radford et al. (1968) suggested, it is similar to the other pendent-flowered lilies in the region, $L$. michauxii and $L$ superbum. However, regional botanists recognized that the turk's-cap lily (L. superbum) per se does not occur in the lower part of the Piedmont, which is the hilly region between the Appalachian Mountains and the inner Atlantic Coastal Plain of which the Sandhills are a part. The Carolina lily ( $L . m i$ chauxii) is quite recognizable by its compact bulb, striking obovate leaves, fragrant flowers, and drier habitat. Speculation therefore centered on a link between the unknown lily and L. iridollae M. G. Henry, a rare endemic lily from the Panhandle region of Florida and adjacent Alabama (Henry, 1946). Indeed, natural heritage programs recorded Carolina populations of L. pyrophilum as L. iridollae (e.g., North Carolina Natural Heritage Program, 1999), and early status reports commissioned because of L. pyrophilum's rarity assumed the Carolina Sandhills lily populations represented a significant range extension for $L$. iridollae. This suggestion was well founded because both overall morphology and the baygall (Magnolia, Ilex), Sarracenia bog, and streamhead habitats of these two species are closely similar. Others (Moretz \& Smith, 1995) suggested that the unknown lily had been previously described from Mississippi as L. gazarubrum M. K. Roane \& J. N. Henry (1980). However, we have examined lilies from very near the type locality of L. gazarubrum in Choctaw County, Mississippi, and have also seen the type, and like Adams (1981), we conclude that $L$. gazarubrum can be accommodated within L. superbum. Extended field and herbarium study and unpublished morphometric analysis ultimately led us to determine that the lily described here is distinctive and new.

Lilium pyrophilum M. W. Skinner \& Sorrie, sp. nov. TYPE: U.S.A. North Carolina: Moore Co., Highway 73 near Pinehurst, 149 m, 4 Aug. 1995 (f), M. W. Skinner 272 (holotype, GH; isotype, MO). Figures 1, 2.

Novon 12: 94-105. 2002. 


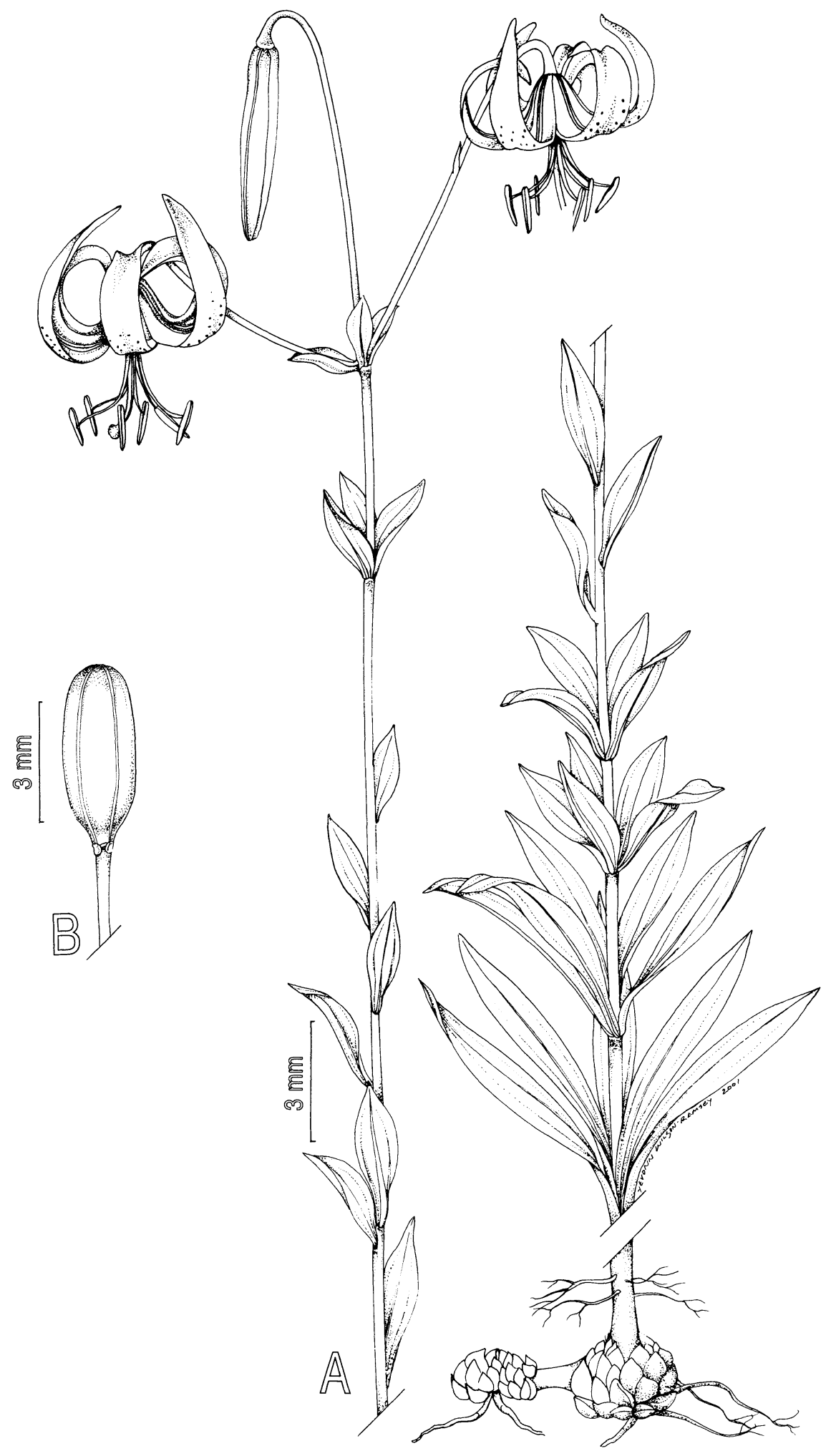

Figure 1. Lilium pyrophilum M. W. Skinner \& Sorrie. -A. Habit with bulb and flowers, based on the type collection (M. W. Skinner 272) from Moore County, North Carolina. - B. Capsule before opening, from a B. A. Sorrie photograph taken at the type locality. 

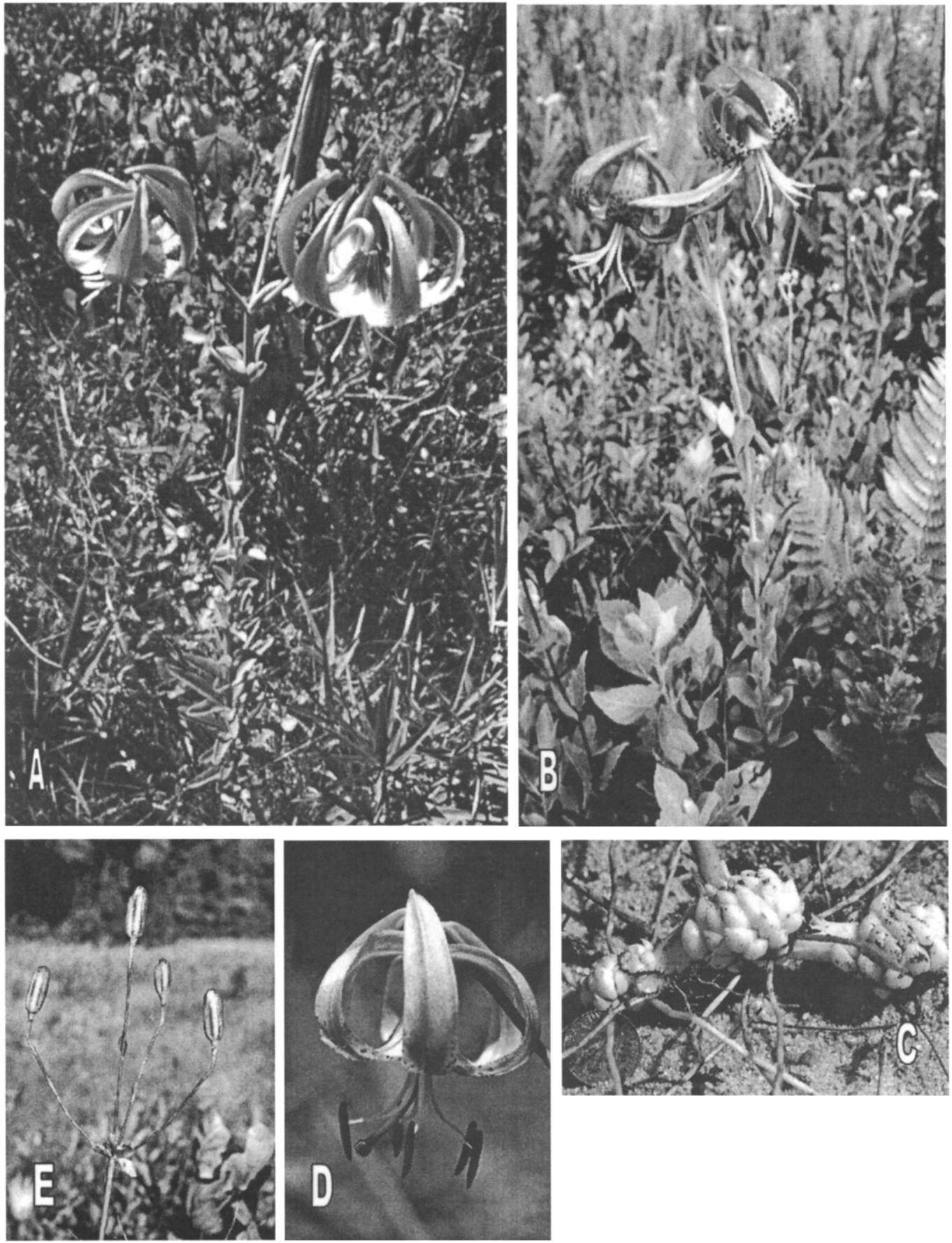

Figure 2. Lilium pyrophilum, photographs A-D by M. W. Skinner, E by B. A. Sorrie. - A. Habit of the type specimen (M. W. Skinner 272). -B. Habit. - C. Rhizome, the next year's bulb at left (M. W. Skinner 267). -D. Flower. -E. Fruiting stalk from the type locality. A, E from Moore County, North Carolina, B-D from Ft. Jackson, Richland County, South Carolina. 
Haec species Lilio superbo L. arcte affinis, sed ab eo anthesi serotina, habitu multo minore, foliis brevioribus atque tubo florali longiore distinguitur; locos perculationis ortusque rivulorum saepe incensos habitat.

Bulb a slowly growing scaly rhizome, horizontal and elongate, $2.4-2.8 \times 5.2-8.6 \mathrm{~cm}, 0.3-0.5$ times taller than long, lacking scales between the 2-3 bulb units that represent annual growth, the young end sometimes dichotomously branched at $120^{\circ}$ from main axis; scales (modified leaves) numerous, fleshy and starchy, unsegmented, longest 1.1-1.9 $\mathrm{cm}$, white; roots on each bulb mostly contractile and thus thick (to $5 \mathrm{~mm}$ ) and often concentrically wrinkled, a few thinner and fibrous. Stems to 1.6 $\mathrm{m}$, erect, \pm glabrous, green, adventitious roots (stem roots) above the bulb sometimes present. Leaves numerous, simple, exstipulate and sessile, the lower leaves scarcely ascending or ascending, drooping at tip or not, upper ascending and appressed, (scattered or) in 0-12 \pm proximal whorls of 3 or more leaves, 3-11(-15) per whorl; blade narrowly elliptic, $2.3-10.3(-12.2) \times 0.8-2.4 \mathrm{~cm}$, 1.6-7.6(-10.3) times longer than broad, apex acute (scarcely acuminate on upper stem), margin entire, usually glabrous, not undulate, green and somewhat lighter below, the major veins 3 , these glabrous below. Inflorescences terminal, racemose (umbellate in small plants) and open, maturing acropetally, 1-7flowered; bracts generally $1-2$ per flower, often one broadly lanceolate and basal to the pedicel, the other narrowly lanceolate, adaxial, and attached near the middle of the pedicel; pedicels $6.8-16.5 \mathrm{~cm}$. Flowers bisexual, pendent, shaped as a "turk'scap," radial (or slightly vertically bilateral as flower matures), not fragrant; tepals free, reflexed $1 / 5-1 / 4$ along length from base, red-orange or dusky red (magenta or pinkish, pale orange, red) apically to (pale) yellow (yellow-orange) centers to visibly green basally, magenta spots concentrated in proximal $1 / 2-2 / 3$, sepals $3, \pm$ lanceolate and narrowed at the base, 6.7-8.9 $\times 1.1-1.7 \mathrm{~cm}$, glabrous, each with an adaxial nectar-bearing surface basally and with two sharp parallel longitudinal median ridges abaxially, apex usually acute; petals 3 and similar to the sepals, $6.3-8.7 \times 1.5-2.2 \mathrm{~cm}$, apex acute, the basal nectaries less extensive than those on the sepals, with two rounded longitudinal median ridges adaxially; stamens 6 , free, opposite the perianth parts, quite exserted; filaments parallel at first then widely spreading at $12-28^{\circ}, 4.5-5.9 \mathrm{~cm}$; usually pale green; anthers versatile, oblong, 1.1-1.8 cm when fresh, magenta (purple), becoming darker; pollen rust-colored, becoming lighter; pistil 1, compound, 3-lobed with 3 chambers, oblong, 3.4-6.4 $\mathrm{cm}$; ovary superior, $1.5-2.8 \mathrm{~cm}$; axile placentae 6 ; ovules as many as seeds, a few developing without embryos; style 1, round in cross section, initially parallel to flower axis but generally elongating and curving toward periphery, pale green and often spotted purple; stigma 3-lobed. Capsules loculicidal, the valves 3 , erect, \pm oblong-obovate, with constricted base, not strongly winged, 2.8-4.7 $\times$ (1.3-)1.5-1.9 cm, 1.7-2.8 times longer than broad, green maturing brown. Seeds many, in 6 ranks, shape a flat $60^{\circ}$ wedge, surface verrucose, light brown with darker ovate embryo in center.

Etymology. The epithet is from the Latin for "fire loving," and is employed here because of the very frequent fires that are essential to maintain proper habitats for L. pyrophilum. Because the species is restricted to the Sandhills of the Carolinas and adjacent Virginia we propose the vernacular name of Sandhills lily.

Phenology. Flowers in summer (late July-mid August); capsules mature in late October.

Distribution. The known range of Lilium pyrophilum extends from southeastern Virginia to southcentral South Carolina, wholly within the Atlantic Coastal Plain. The great majority of populations occur within the Sandhills region, an area of rolling topography dissected by abundant blackwater streams. Although this physiographic region extends from the Carolinas to central Alabama, in terms of floristics and phytogeography the core area extends from Johnston County in east-central North Carolina to Richmond County in extreme east-central Georgia (Sorrie \& Weakley, 2001). We have documented the lily from ten counties in North Carolina, four in South Carolina, and two in Virginia (Fig. 3), at elevations ranging from 25 to $150 \mathrm{~m}$.

The Sandhills region is a significant area of speciation within the North American coastal plain (Sorrie \& Weakley, 2001), and many endemics have been recognized there. The following are distributed exclusively within the core Sandhills region or have the majority of their populations there: $A s$ tragalus michauxii (Kuntze) F. J. Hermann, Liatris cokeri Pyne \& Stucky, Lycopus cokeri Ahles ex Sorrie, Physalis lanceolata Michaux, Pityopsis pinifolia (Elliott) Nuttall, Pyxidanthera barbulata Michaux var. brevifolia (Wells) Ahles, Stylisma pickeringii (Torrey ex M. A. Curtis) A. Gray var. pickeringii, Vaccinium crassifolium Andréanszky subsp. sempervirens (Anderson \& Rayner) Kirkman \& Ballington. Lycopus cokeri is a very frequent associate of Lilium pyrophilum, whereas Liatris cokeri, Physalis lanceolata, and Pityopsis pinifolia occur on adjacent dry to xeric slopes.

Habitat: the physical setting. The Sandhills re- 


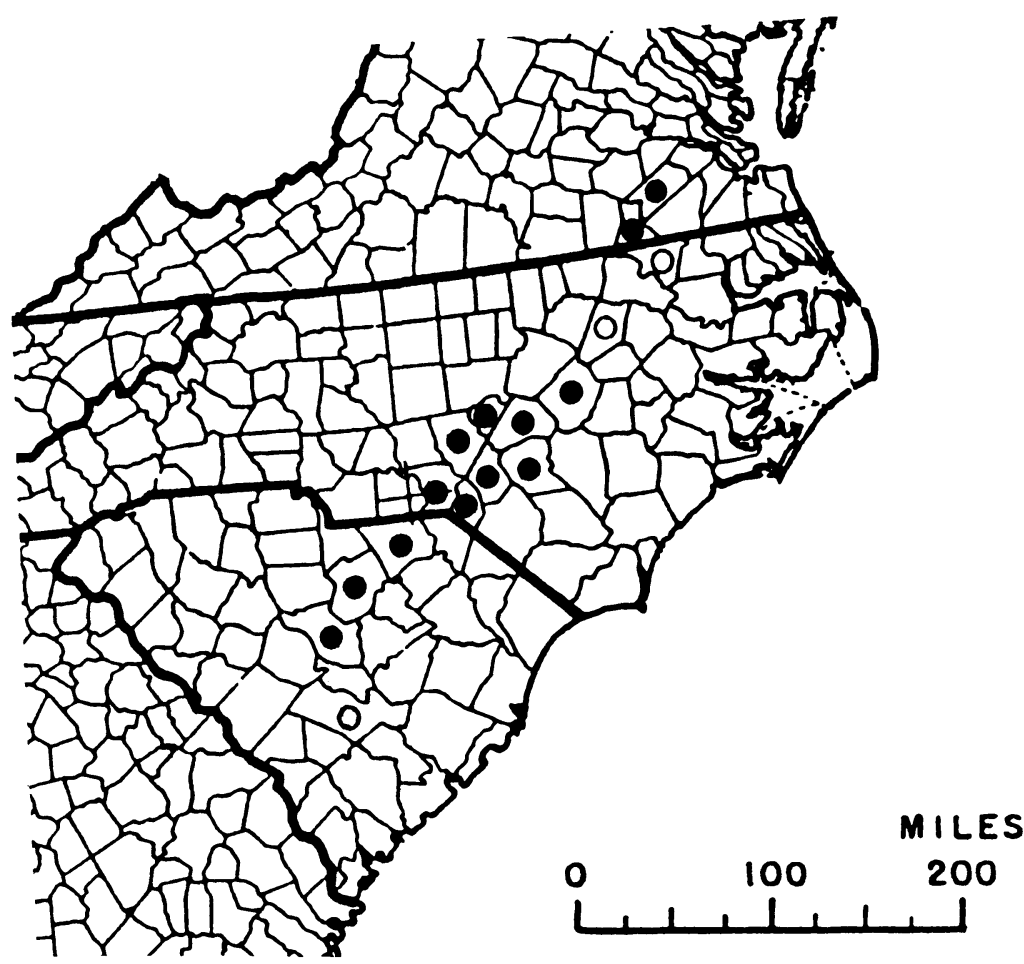

Figure 3. Lilium pyrophilum distribution in Virginia, North Carolina, and South Carolina. Solid circles represent counties with extant populations documented since 1990, open circles counties where the species is historical (pre1990) and presumed extirpated.

gion (also known as the Fall-line Sandhills) constitutes the innermost portion of the coastal plain and abuts the Piedmont physiographic province. The fall-line is a distinct geological boundary separating the younger Cretaceous and Tertiary age sediments to the east and the older Paleozoic formations to the west (Fenneman, 1938). Parent materials of the Sandhills are unconsolidated to partly consolidated sands, gravels, and clays.

Compared with the rest of the coastal plain, topography in the Sandhills is highly varied, with elevations that range from 30 to $180 \mathrm{~m}$ above sea level. The term "rolling hills" is apt; although the region is highly dissected, there are few sharp geomorphic features. Rock outcrops are scarce. Drainage creeks are abundant; most lie $10-30 \mathrm{~m}$ below the surrounding hilltops and small plateaus, whereas larger streams and rivers lie significantly lower. A number of large rivers traverse the Sandhills from their origins in the Piedmont or mountains. All drainages that originate in the Sandhills are dark tea in color due to high tannin content and are termed blackwater streams.

Upland soils in the Sandhills are acidic welldrained sands and loamy sands; subsoils may be sandy throughout, or have a clayey or loamy layer.
Soils of streamheads and creeks are finer loams and loamy sands; those along rivers contain considerable organic matter.

Habitat: plant communities. Lilium pyrophilum occurs almost exclusively in ecotonal situations within the longleaf pine (Pinus palustris Miller) ecosystem. It inhabits narrow transition zonesusually 2 to $10 \mathrm{~m}$-between dry longleaf pine-oakwiregrass uplands and wet, wooded creeks and streamheads. Upland communities (usually longleaf pine-oak-wiregrass with scattered low shrubs) quickly give way to a shrub-cane-fern-herb ecotone, in turn replaced by a tree-shrub-sphagnum streamhead with flowing water. Due to the hilly topography of the Sandhills region and myriad drainage creeks, ecotonal habitats once were abundant across the landscape, but widespread fire suppression and conversion of streamheads to fishing ponds, farm impoundments, swimming ponds, and water reservoirs have severely reduced these plant communities.

Ecologists usually ally ecotonal communities of the Sandhills region with the adjacent wetland communities based on the substantial percentage of shared species versus the much smaller percentage of species in common with adjacent uplands (Schaf- 
ale \& Weakley, 1990). Indeed, there is a mix of upland and wetland plants, but Sandhills ecotones support a significant number of species that do not normally occur in either "parent" community. In fact, some of these species such as pine barren reedgrass (Calamovilfa brevipilis (Torrey) Scribner) and savanna cowbane (Oxypolis ternata (Nuttall) Heller) occur in the Sandhills only in ecotones and related seepage habitats. Phytogeographically, these plants may be considered a subset of those that are characteristic of wet savannas and flatwoods of the outer coastal plain of the Carolinas, particularly the colorful pitcherplants (Sarracenia), meadow-beauties (Rhexia), seedboxes (Ludwigia), milkworts (Polygala), orchids, sundews (Drosera), and yellow-eyed-grasses (Xyris).

Lilium pyrophilum is most closely associated with three distinctive wetland communities, as follows:

1. Streamhead Pocosin. This community occurs along headwaters of creeks and stream branches where seepage water from adjacent ecotones forms definite rivulets. It extends downstream as long as such seepage is important to plants relative to stream flooding. The term "pocosin" is used because the usually dense evergreen shrubs and sparse canopy are reminiscent of true pocosins that develop on peat that accumulates on flatter and younger portions of the coastal plain (Schafale \& Weakley, 1990; Sharitz \& Gibbons, 1982). Typical shrubs and vines are titi (Cyrilla racemiflora L.), fetterbush (Lyonia lucida (Lamarck) K. Koch), inkberry (Ilex glabra (L.) A. Gray and I. coriacea (Pursh) Chapman), highbush blueberry (Vaccinium formosum Andréanszky and $V$. fuscatum Aiton), sweet pepperbush (Clethra alnifolia L.), evergreen bayberry (Myrica heterophylla Rafinesque), redbay (Persea palustris (Rafinesque) Sargent), poison sumac (Toxicodendron vernix (L.) Kuntze), and blaspheme vine (Smilax laurifolia L.). Trees may be sparse or fairly dense, with tuliptree (Liriodendron tulipifera L.), pond pine (Pinus serotina Michaux), swamp black gum (Nyssa biflora Walter), red maple (Acer rubrum L.), sweetbay (Magnolia virginiana L.), and occasionally Atlantic white cedar (Chamaecyparis thyoides (L.) Britton, Sterns \& Poggenburg). Sphagnum moss is usually abundant and cane (Arundinaria tecta (Walter) Muhlenberg) frequent to common.

Streamhead Pocosin ecotones are normally dominated by low shrubs and cane down-slope and herbs and graminoids up-slope, but complex patterns may be produced depending on soil moisture and disturbance. Woody plants are kept short by recurring fires (or mowing in powerlines). Promi- nent shrubs are dangleberry (Gaylussacia frondosa (L.) Torrey \& A. Gray ex Torrey), Clethra alnifolia, Ilex glabra, and I. coriacea, maleberry (Lyonia ligustrina (L.) DC.), swamp azalea (Rhododendron viscosum (L.) Torrey), blueberries (Vaccinium crassifolium and $V$. tenellum Aiton), dwarf witchalder (Fothergilla gardenii L.), and honeycups (Zenobia pulverulenta (Bartram ex Willdenow) Pollard). Important grasses include Ctenium aromaticum (Walter) Wood, Muhlenbergia expansa (Poiret) Trinius, Aristida virgata Trinius, A. stricta Michaux, Dichanthelium spp., Panicum virgatum L. var. cubense Grisebach, Andropogon glomeratus (Walter) Britton, Sterns \& Poggenburg, Calamagrostis coarctata (Torrey) Eaton, and Calamovilfa brevipilis. Conspicuous sedges include Rhynchospora spp. (up to a dozen taxa), Carex glaucescens Elliott, C. turgescens Torrey, Eleocharis tuberculosa (Michaux) Roemer \& Schultes, E. tortilis (Link) Schultes, and occasionally Eriophorum virginicum L. Other frequent monocots include Juncus trigonocarpus Steudel, Eriocaulon decangulare L., and Lachnocaulon anceps (Walter) Morong. The majority of Lilium pyrophilum populations occur in the mid to lower portions of this ecotonal habitat type, and only rarely in the Streamhead Pocosin proper.

1.a. Canebrake Variant. Where burned very frequently, Streamhead Pocosins support fewer trees and shrubs. These are replaced by dense stands of Arundinaria tecta called canebrakes. Species diversity is low relative to normal streamhead communities, although ectones remain diverse. Only small populations (1 to 5 plants) of Lilium pyrophilum occur in this habitat type.

2. Sandhill Seep. This community occurs on slopes where the clay layer abruptly forces water to the surface, usually where there is a sudden increase in the angle of the slope. Sandhill Seeps occur within the upland pine-oak-wiregrass community as a patch of shrubs, ferns, and cane that form a "rim" across the slope. They may be connected to Streamhead Pocosins and Small Stream Swamps, and may have perennially active seepage or be merely moist. Once numerous in the Sandhills region, high quality examples are now rare due to fire-suppression. Lilium pyrophilum appears to be rare in this habitat.

3. Coastal Plain Small Stream Swamp. This community occurs downstream from Streamhead Pocosins where water volume is great enough to cause frequent flooding following rainstorms. It is dominant along the major blackwater streams through the Sandhills region. Canopy dominants are Nyssa biflora, loblolly pine (Pinus taeda L.), Acer rubrum, willow oak (Quercus phellos L.), water oak 
Table 1. Summary of protection of known L. pyrophilum populations.

\begin{tabular}{llcc}
\hline \hline \multicolumn{1}{c}{ Ownership } & \multicolumn{1}{c}{ Type of protection } & Populations & Individuals \\
\hline Private & none & 3 & 16 \\
National wildlife refuge & passive & 1 & $2+$ \\
Military reservation & & & \\
$\quad$ Camp Mackall & passive & 2 & 2 \\
Fort Bragg & passive & 21 & 63 \\
Fort Jackson & passive & 1 & 7 \\
State forest & passive & 1 & $1+$ \\
State game land & passive & 5 & 15 \\
Private with utility easement & management agreement & 6 & 89 \\
State park & active & 1 & 7 \\
Private conservation & active & 1 & 3 \\
& & 42 & $205+$ \\
\hline
\end{tabular}

(Q. nigra L.), sweetgum (Liquidambar styraciflua L.), and scattered pond cypress (Taxodium ascendens Brongniart). Subcanopy trees include American holly (Ilex opaca Aiton), Cyrilla racemiflora, Persea palustris, and Magnolia virginiana. Shrubs and vines vary from sparse to dense and include doghobble (Leucothoe axillaris (Lamarck) D. Don), blackberry (Rubus argutus Link), Smilax laurifolia, greenbrier (Smilax rotundifolia L.), sawbrier (Smilax glauca Walter), poison ivy (Toxicodendron radicans (L.) Kuntze), sweetspire (Itea virginica L.), and crossvine (Bignonia capreolata L.). Herbs are poorly represented, except in light gaps and right along the streambanks. Due to the persistently saturated soils, fire is only a minor component of the ecology of this community. Ecotones to Small Stream Swamps are generally less diverse than those of streamheads due to diminished seepage from adjacent uplands. Only small populations (1 to 5 plants) of Lilium pyrophilum occur in these ecotones.

Rarity, management, and conservation. Lilium pyrophilum is a very rare plant with clearly defined threats. It is highly vulnerable due to rarity within its limited range and patchy habitat, widespread land conversion to other uses, and modern suppression of fires. Today it survives on properties on which prescribed fire is a management tool or where periodic cutting or mowing takes place, such as in powerline and gasline rights-of-way.

The total number of individual plants documented at the 42 known extant (1990-present) populations is approximately 205; there are 11 populations represented only by historical (pre-1990) collections. The 6 largest extant populations number $42,25,15,12,11$, and 10 individual plants; all others hold fewer than 10 plants each, with most limited to 1 to 3 individuals.

Fortunately, nearly all populations receive protection (Table 1) that varies from active conservation to management agreements to passive conservation. Thirty-nine of 42 extant populations and 189 of $205+$ total plants are protected at some level. Although this degree of protection is encouraging despite the small overall population, future prospects remain uncertain. Even if landowners are aware of the lily on their property and wish to foster it, most do not have the resources available to monitor populations nor to conduct specific management protocols. Lilies survive on several properties not as a result of management activities targeted at the plants, but because of the general use of prescribed fire to improve habitat for federally endangered red-cockaded woodpeckers, for improved military troop maneuverability, and for forestry management. On Fort Jackson in South Carolina, exploding ordnance starts the frequent fires that contribute most to habitat maintenance. In utility rights-of-way, lilies survive because periodic cutting to promote human access reduces competition from encroaching woody plants. More sobering is the realization that all four unprotected populations occur on private land in fire-suppressed situations. The general lack of burning within the private sector foretells slim prospects for finding significantly more lilies.

The Sandhills lily currently occupies an extremely narrow range of plant communities, and there is no evidence to suggest that it formerly had wider ecological amplitude. Like its close relative L. iridollae, it appears to be a habitat specialist that requires the unusual combination of saturated soils 
and periodic fire. Within the Sandhills region other rare Carolina endemics such as Kalmia cuneata Michaux and the federally endangered Lysimachia asperulifolia Poiret also share these requirements. Each inhabits the inner portions of the ecotone where shrubs and/or cane are dominant, rather than laterally where graminoids prevail. Disturbance in the form of periodic fire (or cutting of utility rightsof-way) provides a release from competing shrubs and tree saplings, followed by a brief period of a few years when flowering and fruiting take place.

Although we acknowledge the ecological importance of fire to this new lily, we also realize that frequent fire is not a panacea for all members of the longleaf pine ecosystem. Each has its own limits of fire tolerance with regard to frequency, seasonality, and intensity. Research is needed on the specific effects of fire on Lilium pyrophilum. That nearly as many lilies exist in powerlines and gaslines as in areas that burn frequently suggests that mechanical disturbance may be important as well. But what form, if any, did this disturbance take in pre-settlement times? Is it an adequate long-term substitute for fire? To our knowledge no public utility uses fire as a management tool; it should be tried where practicable and compared with traditional cutting. The use of herbicides in rights-ofway is a concern-does it affect the lily? If so, widespread use of herbicides may significantly reduce chances of finding additional populations of the Sandhills lily.

Populations of rare lilies in North America have been decimated in the recent past by collectors and fanciers who hope to appreciate these plants in their home gardens (Skinner \& Pavlik, 1994). These misguided efforts usually end in failure due to the highly specific habitat requirements of most geographically restricted lilies. We encourage botanists and plant lovers to appreciate these plants in the field, and caution that removal of plants from most populations would be in violation of existing state or federal laws.

Biologists and land managers continue to find new populations, but overall numbers remain extremely low. Therefore, we recommend that the U.S. Fish and Wildlife Service consider Lilium pyrophilum for listing under the federal Endangered Species Act, and urge state protection as well.

Similar species. Lilium pyrophilum is one of a monophyletic group of lilies (Skinner, in press) that also includes L. superbum (turk's-cap lily), L. michauxii (Carolina lily), and L. iridollae (Panhandle lily). This species group is characterized by a generally southern distribution in the United States, green styles, large flowers (sepals 5.7-10.5 cm) with large anthers $(1.0-2.6 \mathrm{~cm})$, buds that are triangular in cross section, generally smooth-margined and smooth-veined leaves, sepals with two abaxial longitudinal ridges, and whitish bulbs. The remaining Lilium of eastern North America with pendent flowers also represent a well-formed clade marked by a primarily northern distribution, red styles, smaller flowers (sepals 3.2-9.3 cm) with smaller anthers $(0.4-1.3 \mathrm{~cm})$, round buds with smooth backs, scarious-margined and scariousveined leaves that are therefore noticeably rough, and bulbs that are yellow or become so with age. This group includes Gray's lily (L. grayi Watson), Canada lily (L. canadense L.), and Michigan lily ( $L$. michiganense Farwell). A key to L. pyrophilum and allies follows:

Key to the Lilium Species of the Eastern United States with Pendent Flowers, Green Styles, Triangular Buds, and Twin Abaxial Sepal Ridges

1. Leaves strongly oblanceolate, noticeably pale beneath, somewhat fleshy; flowers strongly fragrant . . . . . . . . . . . . . . . . Lilium michauxii

$1^{\prime}$. Leaves elliptic or weakly oblanceolate, scarcely pale beneath, thin; flowers not fragrant.

2. Rhizomes with 3-4 annual bulbs, 9.6-18.4 $\mathrm{cm}$, scaleless sections between annual bulbs 2.7-5.4 cm; bulb scale leaves or their abscission scars present; leaves subtly oblanceolate; flowers yellow-orange, 1-3; coastal Alabama and western Florida . . Lilium iridollae

2 '. Rhizomes with $2(-3)$ annual bulbs, $5.2-10.2$ $\mathrm{cm}$, scaleless sections between annual bulbs $0.3-3.8(-4.6) \mathrm{cm}$; bulb scale leaves or their abscission scars absent; leaves \pm narrowly elliptic; flowers orange or reddish, $1-20$ or more; southern and eastern United States.

3. Plants $1.2-2.8 \mathrm{~m}$; leaves $7.1-26.1 \mathrm{~cm}$, 3.9-18.4 times longer than broad, usually horizontal or drooping, in 6-24 \pm evenly distributed whorls of 3 or more; flowers red-orange (red, orange) to yellow (yellow-orange) to green basally, $1-20$ or more; Louisiana to Missouri, east to Florida and New Hampshire Lilium superbum

$3^{\prime}$. Plants 0.63-1.6 m; leaves 2.3-10.3(12.2) $\mathrm{cm}, 1.6-7.6(-10.3)$ times longer than broad, usually ascending, in 0-12 \pm proximal whorls of 3 or more; red-orange or dusky red (magenta or pinkish, pale orange, red) apically to (pale) yellow (yellow-orange) centers to green basally, 1-7; Sandhills of Virginia and North and South Carolina ....... Lilium pyrophilum

Of the four taxa, L. michauxii is the most derivative and is easily distinguished by its strongly obovate or oblanceolate leaves that are few in number, darker green above and lighter below, fleshy, and undulate along the margins. Its compact bulb, preference for well-drained sites, and delicately scented flowers with exceedingly wide petals (1.8-2.9 
$\mathrm{cm}$ ) are also distinctive. It is the only pendent lily sympatric with L. pyrophilum. Lilium iridollae is narrowly endemic to Escambia, Santa Rosa, Okaloosa, and Walton Counties in the western Florida panhandle and Baldwin, Escambia, and Covington Counties in adjacent Alabama, and it is allopatric to L. pyrophilum. Although its habitat within the longleaf pine ecosystem is similar, it is morphologically divergent by virtue of an elongate rhizome that retains 3-4 years' growth, the presence of basal (winter) leaves (otherwise known in North American lilies only in the distantly related pine lily, $L$. catesbaei Walter), subtly oblanceolate stem leaves, and particularly long pedicels (to $23 \mathrm{~cm}$ vs. a maximum of 19 in the other three species). Its vibrant and uniformly orange-yellow flowers are usually diagnostic as well.

Lilium superbum is more similar to the Sandhills lily than other congeners. It occurs directly to the north and east of the limited range of L. pyrophilum but is absent to the west through the Piedmont; it then reappears along the Appalachian spine. Overlap in blooming times of the two taxa is moderate (Table 2); thus reproductive isolation is achieved geographically and to some degree phenologically. As its name suggests, L. superbum is taller and more robust than the other lilies within its general range, including $L$. pyrophilum (Table 2). It bears more and larger flowers, has longer and relatively narrower leaves, and has more whorls of 5 or more leaves (Table 2), and these are rather evenly spaced along the stem. Lilium pyrophilum typically has the leaf whorls concentrated toward the bottom of the stem, and the leaves are strongly ascending, which is often characteristic of lilies that occur in very high light environments. Of subtle importance is the shape of the floral tube, which is slightly longer and more tubular in $L$. pyrophilum than in $L$. superbum (Table 2). This may be related to pollinator effectiveness (Skinner, 1988), as the Sandhills lily is pollinated at least partially by hummingbirds whereas L. superbum is almost entirely swallowtail butterfly-pollinated, notwithstanding infrequent visits from hummingbirds. This longer, thinner tube sometimes obscures the noticeable "green star" that is formed by the six areas of nectary tissue in the widely flaring $L$. superbum; instead L. pyrophilum often displays a green triangle formed only by the sepal nectaries.

The rhizomes of L. pyrophilum and L. superbum are closely similar, though the latter tends to grow from a larger bulb as befits its greater stature. Lilium superbum also has a tendency toward longer scales that are two-segmented rather than entire, and a more marked tendency toward clonal growth that is a result of repeated dichotomous branching within the rhizomes.

Phytogeography and theories of origin. We propose three alternatives for the origin of the new taxon. The authors do not necessarily agree on the likelihood of each, but we feel that carefully chosen molecular evidence might be conclusive.

1. As a peripherally isolated derivative of $L . s u$ perbum or its ancestor. This theory acknowledges the phenotypic similarity between these two species and their current lack of sympatry.

2. Hybrid origin. Throughout its limited range $L$. pyrophilum co-occurs with L. michauxii, but it overlaps scarcely if at all with $L$. superbum in the coastal plain of southeastern Virginia. It is conceivable that $L$. pyrophilum arose through past contact between these other two species and has evolved its own suite of morphological, biological, and ecological characteristics. Today, L. superbum and L. michauxii are sympatric over a large area of mountains and piedmont from Virginia to Alabama. Though they rarely produce hybrids (Adams, 1982), the possibility of hybrid origin cannot be excluded as physical conditions and plant genotypes are fluid. Hybrids between L. michauxii and L. pyrophilum are known from disturbed habitats associated with utility rights-of-way, and are best recognized by the fine tepal spots and broad petals of the former species. Whether they occur in more natural settings is uncertain.

3. Common ancestry with L. iridollae. Eleven vascular plant species occur in the Sandhills region of the Carolinas as disjuncts from the Gulf region where L. iridollae grows (Sorrie et al., 1997; Sorrie \& Weakley, 2001), and a number of others share essentially the same pattern of disjunction. Some of these species occur in the same streamhead habitats as L. pyrophilum, including Carex turgescens Torrey, Eriocaulon texense Körnicke, Rhynchospora leptocarpa (Chapman ex Britton) Small, R. macra (C. B. Clarke) Small, R. oligantha A. Gray, Xyris chapmanii Bridges \& Orzell, and X. scabrifolia Harper. It may be significant that these same species also co-occur with Lilium iridollae in the Gulf Coastal Plain, and it suggests that the historical events that introduced these grasslike species to the Sandhills may also have brought a common ancestor of L. iridollae and L. pyrophilum into that region.

The specimens cited below (herbarium acronyms are listed in full in the Acknowledgments) represent seven extant (1990-present) populations, each in a distinct county (the Lee Co., North Carolina, historical collection from 1961 has recently been verified to represent an extant population), and 
Table 2. Major differences between L. pyrophilum and L. superbum. Measurements are means, (ranges), and [sample sizes]; $p$ values indicate the probability that the samples are from the same statistical population, and are from independent sample T-tests performed using Statistica (1999). Fire frequencies are from Frost (1998).

\begin{tabular}{|c|c|c|}
\hline & L. pyrophilum & L. superbum \\
\hline Distribution & Sandhills of SC, NC, and VA & $\begin{array}{l}\text { Coast and mountains from } \mathrm{NH} \text { to } \\
\mathrm{NC}, \mathrm{MO}, \mathrm{LA} \text {, and FL }\end{array}$ \\
\hline Habitat & $\begin{array}{l}\text { streamhead pocosins, sandhill seeps, swampy } \\
\text { streams, wet utility lines; fires extremely fre- } \\
\text { quent (every 1-3 years) }\end{array}$ & $\begin{array}{l}\text { rich, moist woods, roadsides, stream- } \\
\text { sides; fires vary (every 1-100 } \\
\text { years) }\end{array}$ \\
\hline Blooming period & peak in early Aug. (late July to mid Aug.) & $\begin{array}{l}\text { peak in mid-late July (July to early } \\
\text { Aug.) }\end{array}$ \\
\hline Pollinators & $\begin{array}{l}\text { ruby-throated hummingbirds (Archilochus colu- } \\
\text { bris Linnaeus) and palamedes swallowtails } \\
\text { (Papilio palamedes Drury), probably other } \\
\text { swallowtails including spicebush (P. troilus } \\
\text { Linnaeus); relative importance of bird and } \\
\text { butterfly pollinators unknown }\end{array}$ & $\begin{array}{l}\text { large swallowtails, esp. spicebush }(P . \\
\text { troilus), also tiger ( } P \text {. glaucus Lin- } \\
\text { naeus) and pipevine (Battus phile- } \\
\text { nor Linnaeus) }\end{array}$ \\
\hline $\begin{array}{l}\text { Plant height }(\mathrm{cm}) \\
\mathrm{p} \ll 0.001\end{array}$ & $103.4(63-160)[27]$ & $174.4(118-280)[31]$ \\
\hline $\begin{array}{l}\text { Rhizome height } \\
p=0.02\end{array}$ & $26.0(23.9-28.1)[4]$ & $33.4(23.5-43.9)[17]$ \\
\hline $\begin{array}{l}\text { Rhizome longest scale } \\
\qquad(\mathrm{mm}) \\
\mathrm{p}=0.09 \text { (not signifi- } \\
\text { cant) }\end{array}$ & $15.5(11-18.9)[4]$ & $21.8(11.8-39.3)[17]$ \\
\hline Leaf arrangement & $\begin{array}{l}\text { usually whorled, whorls often clustered toward } \\
\text { bottom of plant, lower leaves scarcely ascend- } \\
\text { ing or ascending, drooping at tip or not, up- } \\
\text { per ascending and appressed to stem }\end{array}$ & $\begin{array}{l}\text { always whorled, whorls evenly } \\
\text { spaced on stem, leaves horizontal } \\
\text { and drooping at tips, upper leaves } \\
\text { often ascending in sun }\end{array}$ \\
\hline Leaf shape & narrowly (to broadly) elliptic & $\begin{array}{l}\text { (very) narrowly elliptic (to scarcely } \\
\text { oblanceolate) }\end{array}$ \\
\hline $\begin{array}{l}\text { Leaves per plant } \\
\mathrm{p} \ll 0.001\end{array}$ & $51.0(29-102)[27]$ & $96.5(40-186)[31]$ \\
\hline $\begin{array}{l}\text { Whorls per plant of } 5 \text { or } \\
\text { more leaves } \\
\text { p } \ll 0.001\end{array}$ & $3.9(0-10)[27]$ & $8.4(3-14)[31]$ \\
\hline $\begin{array}{l}\text { Leaf length }(\mathrm{mm}) \\
\mathrm{p} \ll 0.001\end{array}$ & $62.2[23-103(-122)][206]$ & $138.8(71-261)[205]$ \\
\hline $\begin{array}{l}\text { Leaf length/width ratio } \\
\qquad \mathrm{p} \ll 0.001\end{array}$ & $4.1[1.6-7.6(-10.3)][206]$ & $9.9(3.9-18.4)[205]$ \\
\hline Flower color & $\begin{array}{l}\text { muted orange-red or yellow-orange with red } \\
\text { dusting on tips (variable and sometimes red- } \\
\text { dish pink, red-orange, magenta, dusky red, or } \\
\text { salmon), grading to (pale) yellow (yellow-or- } \\
\text { ange) centers to green at base; maroon spots } \\
\text { often large }\end{array}$ & $\begin{array}{l}\text { (pale) red-orange (pale red, red, or- } \\
\text { ange, yellow scarcely suffused } \\
\text { with red) grading to yellow (yel- } \\
\text { low-orange) to green at base; ma- } \\
\text { genta (maroon) spots only in yel- } \\
\text { low and often large }\end{array}$ \\
\hline $\begin{array}{l}\text { Flowers per plant } \\
\mathrm{p} \ll 0.001\end{array}$ & $1.7(1-7)[57]$ & $3.7(0-22)[299]$ \\
\hline $\begin{array}{l}\text { Sepal length }(\mathrm{mm}) \\
\mathrm{p}=0.014\end{array}$ & $78.1(67-89)[25]$ & $83.5(68-105)[37]$ \\
\hline $\begin{array}{l}\text { Floral tube length }(\mathrm{mm}) \\
\mathrm{p} \ll 0.001\end{array}$ & $17.9(13.1-24.3)[25]$ & $13.0(8.9-16.5)[37]$ \\
\hline $\begin{array}{l}\text { Capsule length }(\mathrm{mm}) \\
\mathrm{p}=0.001\end{array}$ & $38.9(28.2-47.0)[21]$ & $45.3(28.8-61.5)[23]$ \\
\hline
\end{tabular}


eleven historical populations (collected prior to 1990). Most of these historical populations have been surveyed but habitat is generally degraded, and we assume the plant is extirpated at each location. Four counties-Nash and Northampton in North Carolina and Kershaw and Orangeburg in South Carolina-are represented only by historical specimens collected before 1990. There are current sight records (North Carolina Natural Heritage Program and South Carolina Heritage Trust databases, 1999) from 35 additional populations that add 4 additional Carolina counties to the total with extant populations, as well as a sight record from 1 additional county of Virginia, Sussex County (B. Van Eerden, pers. comm.). Thus $L$. pyrophilum is currently known from 42 populations in 12 counties, and historically at 11 populations in these and 4 additional counties.

Paratypes. U.S.A. North Carolina: Cumberland Co., 6.8 mi. S of Fayetteville on NC 87, 7 Aug. 1957, H. E. Ahles 33525 (GA, NCU); Harnett Co., wet soil by route 53, 1 mi. S of Pineview, 1 Aug. 1927, H. R. Totten s.n. (NCU); Fort Bragg Military Reservation, Northern Training Area, seep and pocosin complex, 6 Aug. 1993, B. A. Sorrie 7512 with B. Van Eerden \& T. Hippensteel (NCU), 3 Aug. 1995, M. W. Skinner $270(\mathrm{GH})$; Hoke Co., pocosin border 3.9 mi. W of Montrose, 9 Aug. 1957, H. E. Ahles 33802 (NCU); Johnston Co., streamhead under powerline, 20 July 1999, P. McMillan 3900-a with E. Hajnos (CLEMS); Lee Co., wet seepage along railroad, $2 \mathrm{mi}$. S of Lemon Springs, 29 July 1961, A. E. Radford 44148 (NCU); Moore Co., open shrub bog, Hog Island, SR 2026, 31 July 1974, J. H. Carter III 1003 (wwh); seepage areas in powerline near Pinehurst, 9 Aug. 1992, B. A. Sorrie 6746 (bas), 7 Aug. 1993, B. A. Sorrie 7513 (NCU); Nash Co., recently burned dry pocosin on US 64, $2 \frac{1}{2} \mathrm{mi}$. SW of Nashville, 22 July 1949, W. B. Fox \& R. K. Godfrey 2734 (NCSC); Northampton Co., low undrained roadside $3 \mathrm{mi}$. N of Jackson, 2 Aug. 1958, J. W. Hardin 910 (NCSC); Richmond Co., peat sedge bog near US 1, $5 \mathrm{mi}$. N of Rockingham, 24 July 1956, A. E. Radford 14323 (NCU); seepage bog in powerline near Sandhills Game Land, 27 July 1997, B. A. Sorrie 9367.5 (bas), 4 Aug. 2000, B. A. Sorrie 10584 (NCU); Richmond/Scotland Co., near Pine Lake, 30 July 1933, F. Smith s.n. (DUKE). South Carolina: Chesterfield Co., peat sedge bog 8 mi. E of Patrick, 11 Aug. 1956, A. E. Radford 15809 (NCU); Kershaw Co., powerline crossing of a cleared pond pine pocosin, dirt road off US 1, 3 Sep. 1982, D. A. Rayner 1496 (USCH); Orangeburg Co., boggy woodland border $3 \mathrm{mi}$. NE of Orangeburg on SC 33, 19 July 1957, H. E. Ahles 31685 (NCU); Richland Co., Fort Jackson Army Installation, South Impact Area, 15 Apr. 1992, J. B. Nelson 12269 (USCH), 1 Aug. 1995, M. W. Skinner 267 (GH). Virginia: Greenville Co., W of Jarratt in powerline, diverse seepage wetland, 8 Aug. 1991, T. J. Rawinski 11471 (VPI).

Acknowledgments. We thank Cary Norquist of the U.S. Fish and Wildlife Service for inspiration and financial support, Al Schotz for illuminating discussions about relationships in Lilium, and Al,
Jame Amoroso, Scott Gunn, and Bert Pittman for their expertise in the field. Victoria Hollowell's critical reading was salutary, and Gerald Smith and two anonymous reviewers significantly improved the manuscript. We appreciate Yevonn Wilson-Ramsey for her lovely illustration and Roy Gereau for his clever Latin translation, and we gratefully acknowledge the curators of the herbaria we visited [bas (pers. herb. B. A. Sorrie, Whispering Pines, NC), CLEMS, DUKE, FLAS, FSU, GA, HUH, IBE, LSU, MISSA, MO, NCSC, NCU, NO, PH, US, USCH, USNM, VDB (BRIT), and wwh (Weymouth Woods Sandhills Preserve Herbarium, Southern Pines, $\mathrm{NC})$ ] and their institutions.

\section{Literature Cited}

Adams, R. M. II. 1981. Comments on the three new Lilium species described by Roane and Henry. N. Amer. Lily Soc. Yearb. 34: 21-24.

. 1982. Nodding Lilium species of eastern North America [Liliaceae]. Baileya 21: 165-188.

Fenneman, N. M. 1938. Physiography of the Eastern United States. McGraw-Hill, New York.

Frost, C. 1998. Presettlement fire frequency regimes of the United States: A first approximation. Pp. 70-81 in T. L. Pruden \& L. A. Brennan (editors), Fire in Ecosystem Management: Shifting the Paradigm from Suppression to Prescription. Tall Timbers Fire Ecology Conference Proceedings, No. 20. Tall Timbers Research Station, Tallahassee, Florida.

Henry, M. G. 1946. A new lily from southern Alabama and northern Florida. Bartonia 24: 1-5.

Moretz, C. C. \& G. L. Smith. 1995. Lilium gazarubrum Roane and J. N. Henry discovered in North Carolina (abstract). ASB Bull. 42: 143.

North Carolina Natural Heritage Program. 1999. Database records for Lilium "iridollae." Division of Parks and Recreation, Raleigh, North Carolina.

Radford, A. E., H. E. Ahles \& C. R. Bell. 1968. Manual of the Vascular Flora of the Carolinas. Univ. North Carolina Press, Chapel Hill.

Roane, M. K. \& J. N. Henry. 1980. Notes on four lilies from southeastern United States. Quart. Bull. N. Amer. Lily Soc. 34: 25-32.

Russo, M. J. 1997. Status Survey of Lilium sp. nov. [formerly considered Lilium iridollae Henry]. Unpublished report prepared for North Carolina Plant Conservation Program and U.S. Fish and Wildlife Service.

Schafale, M. P. \& A. S. Weakley. 1990. Classification of the Natural Communities of North Carolina. Third Approximation. North Carolina Natural Heritage Program, Division of Parks and Recreation, Raleigh.

Sharitz, R. R. \& J. W. Gibbons. 1982. The Ecology of Southeastern Shrub Bogs (Pocosins) and Carolina Bays: A Community Profile. U.S. Fish \& Wildlife Service, Washington, D.C. FWS/OBS-82/04.

Skinner, M. W. 1988. Comparative Pollination Ecology and Floral Evolution in Pacific Coast Lilium. Ph.D. Dissertation, Harvard University, Cambridge.

. In press. Lilium. In Flora of North America Editorial Committee (editors), Flora of North America North of Mexico, Vol. 26. Oxford Univ. Press, New York. \& B. M. Pavlik. 1994. Inventory of the Rare and 
Endangered Vascular Plants of California. California Native Plant Society, Sacramento.

Sorrie, B. A. \& A. S. Weakley. 2001. Coastal plain vascular plant endemics: Phytogeographic patterns. Castanea 66: 50-82.

B. van Eerden \& M. J. Russo. 1997. Noteworthy plants from Fort Bragg and Camp MacKall, North Carolina. Castanea 62: 239-259.

South Carolina Heritage Trust. 1999. Database records for Lilium "iridollae." Department of Natural Resources, Columbia, South Carolina.

Statistica. 1999. StatSoft, Inc. Tulsa, Oklahoma. 